Journal of Community \& Applied Social Psychology

J. Community Appl. Soc. Psychol., 21: 202-214 (2011)

Published online in Wiley Online Library

(wileyonlinelibrary.com) DOI: 10.1002/casp.1093

\title{
Psychological Citizenship and National Identity
}

\author{
DENIS SINDIC* \\ Institute of Social Sciences, University of Lisbon, Portugal
}

\begin{abstract}
In this paper, I raise the question of whether psychological citizenship (i.e. the subjective sense of being a citizen) is necessarily intertwined with a sense of national identity in our contemporary world. First, I argue that psychological citizenship is always dependent upon a sense of shared identity with the community (be it national or other), and I explore some of the reasons why this is the case. Second, I argue that such sense of shared identity can nevertheless sometimes remain implicit so that in order to assess its impact one may need to look beyond people's explicit statements of identification. Third, I turn to the more specific question of national identity and argue that such identity presents particular characteristics that make it consonant with the notion of citizenship (and thus able to sustain a subjective sense of citizenship) in ways that other identities might not always be. Finally, I compare a psychological citizenship based on national identity to one which would be based on a 'global' or 'cosmopolitan' identity. I argue that, whilst the former constitutes a pervasive social psychological reality, doubts can be raised as to whether this is the case for the latter, and thus as to whether it can form a credible alternative to national identity as the psychological substrate of citizenship. I conclude with some reflections concerning what different approaches of social psychology can bring to the study of the psychological aspects of citizenship. Copyright (C) 2011 John Wiley \& Sons, Ltd.
\end{abstract}

\section{INTRODUCTION}

Citizenship and nationality: Nowadays, these terms are virtually interchangeable, at least if considered at the legal and administrative level. To be a citizen is to be a citizen of a specific country. Even the shaky concept of European citizenship is no real exception, for such citizenship can only be gained through being a citizen of one of the member-states in the first place.

Nonetheless, the concept of citizenship is not merely legal but also encompasses political and psychological dimensions - as does, of course, the idea of nationality. One could therefore ask how much citizenship and nationality are intertwined at these levels. In particular, the question which will be addressed in this paper is to what extent a

\footnotetext{
* Correspondence to: Denis Sindic, Institute of Social Sciences, University of Lisbon, 9 av. Prof. Anibal de Bettencourt, 1600-189 Lisboa, Portugal. E-mail: denis.sindic@ics.ul.pt
} 
psychological sense of citizenship relies and depends upon the existence of a sense of national identity.

The importance of this question arises from the fact that some scholars (e.g. Baubock, 1994; Habermas, 1998; Parekh, 2003) have argued for the necessity of going beyond the nationality-based model of citizenship. Needless to say, this is a debate with crucial political implications given that it concerns the future of citizenship and its institutions. Yet, the credibility of alternative institutional models of citizenship does not merely depend on their legal or social or political merits (which will not be discussed here), but also on whether they can be grounded in the social psychological reality of how people experience their citizenship. In that context, the extent to which, in our contemporary world, psychological citizenship is necessarily bounded with a sense of national identity or can be anchored into other forms of identification, and whether there are indications that this is changing or likely to change, should therefore constitute key aspects of the debate.

\section{PSYCHOLOGICAL CITIZENSHIP AND IDENTITY}

To try and bring some light on these questions, one could start by asking whether and why psychological citizenship should require a sense of identity at all. At a basic level, one can define psychological citizenship as the subjective sense of being a citizen. That is, it implies seeing one's status of citizen as more than a mere external and objective ascription and thus to subjectively care about such status and what it entails in terms of rights, benefits and responsibilities. Yet, it is often assumed that such subjective citizenship also goes with a sense of identity. For instance, Kostakopoulou (2008) defines citizenship as 'equal membership of a political community from which enforceable rights and obligations, benefits and resources, participatory practices and a sense of identity flow' (p. 1). Such definitions, then, take identity as a necessary correlate of (psychological) citizenship. But why exactly should it be so?

Conceptually speaking, one could point out that, if citizenship is a status accorded in virtue of belonging to a specific political community, then it follows that people need to see such community as actually corresponding to their community if their objective status of citizen is to have any psychological resonance. That is, it implies the feeling that the scope of the institutions of citizenship corresponds to one's community, and that one is a legitimate member of that community (i.e. the community is part of one's self-definition), and entitled to the status of citizen and its associated rights and benefits (as well as bounded by its associated responsibilities) for that very reason. Similarly, as one cannot feel like (or indeed be) a citizen in isolation, psychological citizenship also implies seeing others as fellow citizens. That is, it presupposes the perception that I and others are part of the same community (however, it is defined), sharing the same political horizon-and thereby entitled to the same citizenship status, associated rights etc.- as opposed to being an arbitrary aggregate of people belonging to different communities and to what are (or should be) essentially separate polities.

To this conceptual argument, one could add that, without such a common sense of identity, it also becomes difficult to understand (amongst other things) how the reciprocity expected among fellow citizens can be made legitimate and even normative. As Reicher and Haslam (2009) point out, in the context of helping behaviour, whilst the question 'will we help others?' may be a relevant one, the question 'will we help ourselves?' is a no-brainer. Similarly, a sense that we are all part of the same community provides the 
conditions under which the act of recognizing others as citizens with the same rights and duties as oneself, and with whom we are in a relation of reciprocity, is not only legitimate but a simple matter of taken-for-granted common sense-as opposed to a more volatile act of altruism or a calculated exchange of 'courtesy'.

What is more, the scope of the reciprocity created by the sharing of a common identity is arguably not limited to the acknowledgement of each others' rights. For instance, in a speech given in 2008 and dedicated to the importance of identity in politics, the UK Minister of State Michael Wills argued that identity is at play in something as material as the tax system: '. . . the redistribution that is inherent in the tax system is only sustainable within the framework of a politics founded on a shared identity and community of interest, where citizens are committed to reciprocal rights and responsibilities.' (2008, p. 1). Indeed, if it were not for the often taken-for-granted assumption that we are part of the same group, it would be difficult to legitimize the very idea of redistribution of wealth and any sort of distributive justice (Habermas, 1998; Miller, 1995, 2000), or for that matter any political decision in which some stand to lose out for the sake of others and/or in the name of the general interest (Barry, 1991). This is because the people on the losing end of these decisions would have no reason to accept them as legitimate and democratic if they do not see losers and winners as part of the same 'we' (Marks, 1999). In other words, a common identity is what makes possible to talk about 'our' common interest as a group in the first place. Accordingly, it is also what legitimates the idea of majority rule at the heart of modern democracy (Scharpf, 1996) as it defines the majority as 'our' majority. Thus, if identity defines the political community as being 'ours', it is also what defines this community as the particular demographic scope within which democratic politics and citizenship can operate legitimately (Calhoun, 1995) ${ }^{1}$.

\section{A PSYCHOLOGICAL CITIZENSHIP WITHOUT IDENTITY?}

Nevertheless, the argument of a necessary relationship between psychological citizenship and identity has to face one potential criticism. Indeed, one difficulty is that such relationship can sometimes be explicitly rejected by citizens themselves. For instance, in their study on national identities in Britain, Abell, Condor, and Stevenson (2006) note that many people in England and Scotland 'avoid social identity constructions of nationality, citizenship, or civil society'. In Scotland, people who support the Union in Britain often 'distinguish their political commitment to British citizenship from questions relating to their subjective identity', whilst in England, many tend to avoid any 'allusions to a common or distinctive identity or character on the part of the citizenry' (p. 207).

However, in both cases, it could be argued that what these respondents reject is a particular idea of identity (in the sense of commonalities between people), which does not prevent identity (as the sense of being part of a community) to operate, even if this might be

\footnotetext{
${ }^{1}$ Space limitations prevent me to discuss here many other arguments (as well as their respective merits and/or weaknesses) that have been put forward in terms of grounding the necessity of identity for citizenship and the good functioning of a political community. This includes, for instance, the fact that identity provides a framework that makes sense of the social world (Taylor, 1994), the stability necessary to make meaningful decisions (Kymlicka, 1995), and a sense of continuity with the past as well as a vision for the future (Tamir, 1993). Note, however, that although most of these arguments have been made in the context of national identity, their logic could very well be extended to other types of identities. This is why so far my point is only made in terms of identity in general and as regards the sense of forming a community, be it national or other. The question of the specificity of national identity is addressed later on.
} 
in implicit ways. Indeed, what Abell et al.'s research shows is that both English and Scottish respondents who resist the language of 'British identity' do so insofar as they take it to mean that people across Britain are alike. For those English who espouse liberal individualist values, such understanding of 'identity' goes against their ideal of pluralism and diversity, and they tend to associate any display of national identity with intolerance and xenophobia (Condor, 1996, 2000). As for the Scots, the idea that people in England and Scotland would be alike clearly clashes with their sense of Scottish specificity. But Abell et al.'s point is precisely that both English and (non-separatist) Scots use spatial references instead - the idea of that 'We are an Island', that we are the 'British Isles' - to maintain the idea of Britain as a real and distinct political community of which they are a part.

Thus, to focus on the case of Abell and colleagues' Scottish respondents, whilst they may resist the idea of 'feeling British', they nevertheless justify their political commitment to Britain on the basis that they live in Britain and that this 'objective' fact must be acknowledged (e.g. 'you've got to accept it, the island of Britain/Yes, we're British', p. 213). This also means that they construe the interests and fate of the Scots and the English as inescapably intertwined, given that they share the same geographical space (e.g. 'there's a lot of issues that it is the whole of the British isles, because we aren't a separate island. We are still one country', p. 215; one can note here the use of the 'we' as well as the description of Britain as 'one country').

In other words, whilst these respondents may treat their 'Britishness' as a purely objective fact, separate from all questions of subjective identity, their statements nevertheless carry specific (and potentially contestable) assumptions as to the existence of a British community as well as to Scotland's inclusion within that community. That such assumptions are hardly neutral becomes even more apparent if we contrast such statements with those made by Scottish separatists. Compare the above, for example, with the following extract taken from an interview with a candidate for the Scottish National Party (Sindic, 2010).

...when anyone asks me about Britishness, I say, I never have been British, I am not British, and never will be British, I am a Scot. I see myself first as Scottish, and then as part of Europe. Scotland is a nation within Europe. So I am Scottish, I'm European, I'm not British. There's no such thing as a British person. They're English, Irish, Scottish or Welsh... And being said, well, you know, you live in Britain, or the British Isles, I say, well, so is the republic of Ireland, but I very much doubt they'd thank you for calling them British.

Here, it is more than the subjective notion of 'feeling British' which is rejected, as this respondent states quite categorically 'I am not British', as a matter of fact-and, what is more, a fact which is valid not only at a personal level but for all Scots (and English and Welsh and Irish people), as 'there's no such thing as a British person'. Indeed she explicitly addresses the idea that being British is an 'objective' fact to be acknowledged, on the basis that Scots live within the 'British Isles', by putting into question the very notion of the 'British Isles' as a merely 'factual' way to designate space — and thus 'British people' as the merely 'objective' way to designate the people living within that space. She does this through a reductio ad absurdum, using the Irish example to push the logic of the appellation until its inadequacy is exposed (as it would include people who are 'objectively' not part of Britain). If Scotland is to be part of a wider geographical area, then the significant space within which it is situated is Europe and not Britain ('Scotland is a nation within Europe').

In sum, what this contrast illustrates is how representations of place can be shaped by various political understandings and articulate with different representations of identity 
(e.g. Hooson, 1994). Accordingly, far from being a purely neutral and objective matter, geography and territory as ways to define who forms a community (and/or who does not) can be as much open to political argument (e.g. what area constitutes a single territory, part of a territory or several distinct territories) as culture or national character (Reicher \& Hopkins, 2001).

More generally, the use of geographical imagery is but one example of how the feeling of forming a community does not have to rely on representations of people as similar (Condor, 2006; Crump, Hamilton, Sherman, Lickel, \& Thakkar, 2010). Most importantly for our present purpose, it thereby illustrates how taken-for-granted assumptions about identity and community can be at play even where people reject any form of common character or culture and/or explicitly deny any strong emotional attachment to their 'objective' community. Certainly, one should be careful to distinguish between external category ascription and the subjective importance of that category for social actors (e.g. see Fenton, 2007). Nevertheless, it is also true that such subjective importance may remain implicit to the actors themselves in their daily life (Billig, 1995) — until their identity is challenged, denied or put within an unfamiliar context where it cannot be taken for granted anymore. To take a simple example, people may well reject all notion of national pride or patriotism and yet feel like they are leaving 'home' when moving abroad as opposed to moving to another city of 'their' country (Hopkins, Reicher, \& Harrison, 2006; Reicher, Hopkins, \& Harrison, 2006).

\section{PSYCHOLOGICAL CITIZENSHIP AND NATIONAL IDENTITY}

Psychological citizenship may require identification with the community, but none of the reasons given above require per se that that identification should be with the national community. To answer the question raised at the beginning, one should therefore now ask whether or not psychological citizenship necessarily relies on a sense of identity that is specifically national.

Of course, at one level, the answer to this question clearly has to be negative, given the historical contingency of the relationship between nationality and citizenship. Since the notion of citizenship existed well before the advent of the nation-state (e.g. Hobsbawm, 1990), its subjective dimension must therefore have relied on other forms of identifications at other points in time and in different political contexts. It would be thus be absurd to reify this relationship as a natural necessity.

Bearing this fact in mind, one could nevertheless raise the question of whether there is anything specific about national identity that would make it consonant with the notion of citizenship — and therefore a suitable basis for psychological citizenship —in ways that other contemporary identities might not always be. In that respect, if we follow Anderson (1991) and argue that the specificity of the nation resides in the particular style in which the national community is imagined (an issue highly relevant to the social psychology of nationhood), the question becomes how much the particular traits of the national imagination are compatible or not with the style in which a 'community of citizens' is imagined.

More specifically, Anderson argues that one aspect of the national imagination is that 'regardless of the actual inequality and exploitation that may prevail in each, the nation is always conceived as a deep, horizontal comradeship' (p.7). That is, not only is there no inherent hierarchy amongst the members of a nation, but national membership is supposed 
to actively 'bracket' any hierarchical differences (of social status, class, profession, wealth, etc.) that might otherwise exist. Likewise, since its birth with the Greek polis, citizenship has always fulfilled a similar 'equalising' role. For the ancient Greeks, its function was to establish equality de jure amongst those who were called upon to take part in political life, precisely because an inequality de facto reigned amongst them. Such 'levelling' was deemed necessary because true democratic politics — as opposed to tyranny — could only take place between 'equals' (Arendt, 1958). Today, modern citizenship is still aimed at guaranteeing equalities of rights (and duties) whatever inequalities might otherwise exist (e.g. Marshall, 1950; see also the definition of citizenship as equal membership quoted at the beginning).

In fact, one may argue that a nationality-based conception of citizenship goes further than its Greek ancestor in terms of its 'equalising' effect. Indeed, citizens of the Greek citystate imagined themselves to be different from and superior to barbarians, precisely insofar as they were citizens, and thus had a true political life, within which political business was resolved through speech and concerted action-whereas barbarians, like animals, only knew the law of the mightiest (Arendt, 1958). By contrast, for the national citizens of today, imagining the national community is imagining it within a world of similar national communities (Billig, 1995). De facto inequality may of course exist between those nations (in terms of power, status, etc.), like it does amongst citizens, but the imagined world of nations is one where all nations, be they small or large, powerful or inconsequential, are de jure equal political actors, and where all, in principle, are entitled to the same rights (from sovereignty in internal affairs, to having its own Olympic team) and duties.

The modern, nationality-based, concept of citizenship is therefore also arguably more inclusive than its ancestor, insofar as it possesses a more universal scope. This is not because nowadays women are counted as full citizens or because slaves have disappeared - both of those classic exclusions of the Greek polis also took place at some point in the age of nations. Rather, it is because, in the imagined world of nations, the whole of humanity is seen as divided into nations, so that all (even foreigners) are supposed to have a nationality and thus to be citizens of some place, instead of some being citizens and other 'barbarians' (although this of course leaves the thorny issue of the potential political exclusion of residents in foreign countries).

To be sure, whilst the above characteristics may be specific to national identity, they may not be exclusively so. One could therefore reiterate the argument that national identity may not be the only type of identity potentially consonant with the notion of citizenship. The point, however, is that there are certainly some types of identities which are not so accommodating. To take just one case in point, it would be difficult, for instance, to imagine a concept of (equalizing) citizenship compatible with the (inherently hierarchical) caste system in India (Dumont, 1971).

Furthermore, besides this issue of 'compatibility', and as pointed out at the beginning, the question of the 'necessity' of national identity for psychological citizenship is also whether, empirically speaking, national identity is indeed the basis for most people's identification with their citizenship community in our contemporary world, or whether such identification might find its sources elsewhere-as well as whether or not there is good reason to believe that this is likely to change in the foreseeable future. This question is touched upon in the next section, through a comparison with one of the possible alternatives to a psychological citizenship based on national identity. 


\section{A PSYCHOLOGICAL CITIZENSHIP WITHOUT NATIONAL IDENTITY?}

If national identity might not be unique in terms of being potentially able to psychologically sustain the idea of a community of citizens, then one could also address the question of its necessity by turning it around and asking what, if any, are its plausible alternatives. In particular, the most notable alternative to a nationality-based conception of citizenship lies with the concept of global citizenship (e.g. Baubock, 1994; Giddens, 1990; Habermas, 1994; Parekh, 2003). Psychologically speaking, such a conception of citizenship relies on the idea that people may (and should) see themselves as citizens on the basis of a 'global' or 'cosmopolitan' identity, i.e. to see themselves as 'citizens of the world'. Like national identity, the idea of a global identity has the advantage of being potentially consonant with the notion of citizenship, insofar as it also constitutes (at least in theory) an essentially equalizing form of identification. Moreover, for the proponents of global citizenship, the main merit of such form of identification resides in the fact that it would overcome the inherent exclusiveness of national identity - as the latter is always both exclusive and inclusive in nature.

As it stands, there is of course little or no legal, political or institutional basis for the notion of global citizenship (Lagos, 2002). The closest thing that could be seen as providing such framework is the Universal Declaration of Human Rights; however, the possible enforcement of those rights is still very much the matter of national states. Nevertheless, the argument that it constitutes a realistic alternative to a nationality-based citizenship is based on the claim that a 'global' or 'cosmopolitan' identity corresponds to a growing social psychological reality. That is, it is argued that globalization has induced (and, increasingly, continues to do so) changes in everyday practices which have affected how people think about themselves and where their loyalties lies. As authors like Anderson, (1991), Billig (1995; see also Calhoun, 1991) and Brubaker (1996) have shown, the creation and maintenance of national sentiments and of the very idea of a national community depend upon the existence of nationalist practices which frame our everyday life, and through which people of the same nation can imagine themselves as sharing the same experiences and information. Yet, with the advent of globalization-or so it is argued-, nationalist practices are becoming rarer whilst 'global' ones are becoming more frequent (e.g. Fraser, 2007; Hannerz, 1996). To take but a couple of examples, nowadays people are exposed to and can access information about what is happening outside as much as within their nation, so that the feeling of sharing similar information with others may no longer be concomitant with the limits of the nation. Also, the increased ease with which we can travel around the world and communicate with anyone regardless of their localization means that social networks of acquaintances and friendships do not have to be limited by geographical factors as they used to be, and can easily cross over national boundaries. The argued consequence of changes such as these is that people see themselves increasingly as part of a 'cosmopolitan' or 'global' community instead of national ones (e.g. Gergen, 1991). Thus, whilst legal citizenship remains nationality-based, people's psychological sense of citizenship could very well be underpinned by an identification with and commitment to the global, rather than national, community.

However, serious questions can be raised as regards the solidity of this narrative. To begin with, one could question whether so-called 'global' practices really transcend the nationality-based system of categorization. That is, does the fact that they are characterized by an international dimension (in the sense that more than one nation is involved) necessarily make them truly transnational (in the sense that nationality is irrelevant, e.g. see 
Conway \& Singh, 2009)? For instance, newspapers may perhaps contain more international information than they did in the past, but as long as this information is categorized as national versus international, the system of national categories remains. Likewise, whilst one can easily order goods on the Internet from various countries in the world, posting charges will soon be a reminder that which nation one is residing in still matters.

Furthermore, where explicit national markers are missing from practices, there is the question of whether this reflects a true nationality-blind cosmopolitanism or whether it is the expression of taken-for granted, banal nationalism and/or of hegemonic nationalism or cultural imperialism (Smith, 1998; Tomlinson, 1991; Young, 2003). The most obvious example is the way American products or practices are often taken for granted as globalthus American movie stars are just 'stars' and there is no 'google.co.us' but only 'google.com'. More generally, whilst in theory a global community is supposed to be imagined as all-inclusive, in practice one must consider the possibility that it may lend itself to ethnocentric projections (e.g. cf. Waldzus, Mummendey, Wenzel, \& Weber, 2003), whereby such global community is imagined as the national community writ large, sharing its same essential characteristics.

All of this therefore raises the question of whether globalization has indeed led to the 'fragmentation' of national identities and to a concomitant rise in cosmopolitan or global identity as much as it has been claimed. And indeed, empirically speaking, data from largescale social surveys do not seem to strongly support that scenario. Thus, on the one hand, there is little indication that national identities have been declining in any significant way in the last decades (e.g. Antonsich, 2009; Heath \& Roberts, 2008; Rose, 1985; Sindic, 2008; Smith \& Jakko, 1998). For instance, the Eurobarometer data shows that across European countries (and with the only exception of Germany), only a minority of 2 to $15 \%$ of the population currently reject all sense of national pride (data from 2005), and that such pride has in fact increased in most countries (with the exception of Spain and Northern Ireland) from 1982 to 2005 (Antonsich, 2009). What is more, as already hinted to above, one could also debate the meaning of such rejection: Does it reflect a real disengagement with national identity (Fenton, 2007), or does it reflect, at least in part, a distancing from some of the negative connotations associated with the idea of 'national pride' and/or ideological norms against the open expression of national identity (Condor, 2000; Billig, 1992) ${ }^{2}$ ? Whatever that may be, national identities remain a strong focus of people's loyalties, and, for the better or the worse, are likely to remain so in the foreseeable future (Sears, Davies, \& Reid, 2008; Sindic, 2008).

By contrast, the evidence in favour of a continuous rise in global or cosmopolitan identity is so far mitigated at best - especially if the claim is that such identity is replacing and transcending national identities instead of complementing or growing out of them. Thus, for instance, whilst Norris (2000) argues, on the basis of the World Values Survey, that the proportion of people seeing themselves as 'cosmopolitan citizens of the globe' has significantly increased amongst those born after the second world war compared to those born before (rising from about 1/10th to about 1/5th of the population), the very data she relies on also shows little if any significant difference amongst the different cohorts born after the war. One could therefore question whether such finding is necessarily predictive of a trend towards further increase as opposed to the result of a one-off historical event. What is more, her definition and operationalization of the concept of "cosmopolitan citizens of

\footnotetext{
${ }^{2}$ In that respect, the exception of Germany may be significant given the history of the word 'nationalism' in that country.
} 
the globe' is of those 'identifying with their continent or the world' (p. 175), thus conflating two things (and two figures) that may not be the same (in particular in Europe, where a the existence of the EU means that an European identity might arguably differ from a global one), as well as assuming that such territorial identification necessarily means seeing oneself as a citizen of the globe. Whatever that may be, even if we accept Norris' generous verdict, in absolute terms a cosmopolitan identity is still far from defining the majority of people (at best $1 / 5$ th of the younger generations) as well as far from competing in strength with the proportion of people who, according to the same data, see nationality as their primary territorial identity.

In sum, the above data seems to support Smith (1998)'s conclusion that 'To date, we cannot discern a serious rival to the nation for the affections and loyalties of most human beings' (p. 195). What is more, if the strength and pervasiveness of national identities have so far not been affected by globalization as profoundly as some have argued, nor has it lead them to be replaced en masse by a global or cosmopolitan identity, then there is good reason to be at least sceptical as to the claim that this is going to radically change in the near future (but see Passini \& Morselli, 2011).

Of course, to answer more fully the question that concerns us here, it would remain to be investigated in more detail how exactly national and/or other forms of identification relate to subjective feelings of citizenship. If one can question Norris's assumption that identifying with one's continent and/or the world necessarily entails seeing oneself as a cosmopolitan citizen, the very same question could be raised about the relationship between identifying with one's nation and seeing oneself as a national citizen. Nevertheless, this does not alter the fact that, currently, whilst a nationality-based model of citizenship can potentially rely on a strong social psychological reality which is the pervasiveness of national identities, the same can hardly be said for the ideal of a global citizenship. That is, it remains to be shown that a global or cosmopolitan identity, on which such global citizenship is supposed to rely, is so far more than an utopian ideal (or an expression of hegemonic nationalism) and that it constitutes an actual social and psychological reality for the majority of citizens, as opposed to an elite minority.

\section{CONCLUSION}

The goal of this special issue was to explore the ways in which psychology may help to improve our understanding of citizenship. In line with this goal, I have focused here on pointing out how the investigation of identity issues, and of national identity in particular, is not only useful but necessary if we are to bring some light on the social psychological dimensions of citizenship. More specifically, I argued that (a) psychological citizenship has to be rooted in a sense of identity - albeit one that does not necessarily equate with perceived similarity or homogeneity, and (b) that it is difficult to see what, nowadays, and for the great majority of people, are the credible alternatives to such identification lying primarily with the national community. Whilst it is important not to reify the relationship between psychological citizenship and national identity as a natural necessity, the latter seems to be currently the only form of identification that is both psychologically consonant with the notion of citizenship and a pervasive social psychological reality.

Of course, my argument has been no more than a rough sketch suggesting some avenues of investigation that would need to be further explored. The overall message is that, whilst the study of the social psychological correlates of citizenship is important, and that 
(national) identity should figure in key place amongst them, such work nevertheless remains mostly to be done, as direct applications of social psychological theories of identity to the issue of citizenship are still sparse. Yet, such work is all the more important given the fact that debates by political theorists on the merits of various institutional and legal models of citizenship always rely, implicitly or explicitly, on social psychological assumptions (i.e. what are the psychological effects or conditions of citizenship practices and institutions), but rarely address directly, as Norris (2000) points out, the question of whether such assumptions can actually be grounded into empirical reality.

In making these points, I have purposefully avoided referring to the debates between different theories and approaches within social psychology that deal with the issue of identity - in particular the debates between 'traditional' approaches such as Social Identity Theory and more 'critical' approaches such as discursive or rhetorical psychology - and what their different contributions to the study of citizenship might be - as this would have led us too far astray. However, such issues are never very far from the surface and inevitably informed my argument. It may therefore be helpful to conclude with a quick (and more explicit) word on this subject.

Two short points can be made: One about identity in general, and one about national identity in particular. To start with the latter, I have explored briefly the way in which the specificity of the national imagination may be important to consider in a world where citizenship is defined by nationality. In that respect, it is clear that a theory like Social Identity Theory (SIT; Tajfel \& Turner, 1979; Tajfel, 1981), however, useful it might be in drawing our attention to generic identity processes, is limited precisely because of its generic focus (Billig, 1996). For SIT, different social identities may provide different contents (meanings, norms and values), but they are otherwise formally interchangeable. There is no notion that different types of identities may be linked with different ways of imagining what being a community and having an identity in themselves mean and entail.

The second point relates to the argument that identity and self-conceptions can sometimes operate in ways that are not always explicitly acknowledged by social actors. Again, this points to the limits of the research carried out within the framework of SIT, given that such research typically relies on scales on which people have to report their explicit degree of identification - and given that the issue is not merely one of variation in the contextual salience of identity (Turner, Oakes, Haslam, \& McGarty, 1994). This is not to say that such scales are not useful. Clearly, there are lot of situations in which people claim explicit identification with (or even pride in) their nationality, and clearly this has important psychological implications. The point is simply that one should also be aware of the limits of these scales, i.e. that what they measure do not exhaust the scope of the psychological processes of identity.

In that framework, and as the above 'lesson in geography' has illustrated, discursive or rhetorical approaches to social psychology can prove useful insofar as they are wellequipped to analyse the taken-for-granted meanings and assumptions in language that betray the implicit workings of identity (e.g. Antaki \& Widdicombe, 1998) - such as for instance the use of 'deictic' expressions (words like 'us', 'our', 'here', 'this' country, etc., see Billig, 1995; Condor, in press). However, not only such approaches cannot replace the necessity of quantitative data when it comes to make large-scale claims as to the spread and strength of identities amongst populations, but there is nothing to say that the very issue of implicit identification is by definition closed to more quantitative approaches. In the past two decades or so, quantitative social psychologists have shown immense creativity in developing new ways to measure implicit forms of racism and prejudice. There is no a 
priori reason why such creativity could not also be applied here. This is not just a question of developing new, perhaps 'automatic' measures of identification whereby people are unable to consciously control their answers. It is also a question of thinking about the situations in which implicit identification can be indirectly revealed through its effectswhen and where, for instance, identity is denied, contested or threatened, and so that its impact comes to the foreground.

\section{ACKNOWLEDGEMENTS}

The author thanks Susan Condor, Jorge Vala, Cicero Pereira, Manuela Barreto and the other members of the GCIR in Lisbon for their very helpful comments on this manuscript.

\section{REFERENCES}

Abell, J., Condor, S., \& Stevenson, C. (2006). 'We are an island': Geographical imagery in accounts of citizenship, civil society and national identity in Scotland and in England. Political Psychology, 27, 191-217.

Anderson, B. (1991). Imagined communities: A reflection on the origin and the spread of nationalism, (revised edn). London: Verso.

Antaki, C., \& Widdicombe, S. (1998). Identities in talk. Thousand Oaks, CA: Sage.

Antonsich, M. (2009). National identities in the age of globalisation: The case of Western Europe. National Identities, 11, 281-299.

Arendt, H. (1958). The human condition. Chicago: The University of Chicago Press.

Barry, B. (1991). Democracy and power: Essays in political theory. Oxford: Oxford University Press.

Baubock, R. (1994). Transnational citizenship: Membership and rights in international migration. Aldershot, England: Edward Elgar.

Billig, M. (1992). Talking of the royal family. London: Routledge.

Billig, M. (1995). Banal nationalism. London: Sage.

Billig, M. (1996). Remembering the particular background of social identity theory. In W. P. Robinson (Ed.), Social groups and identities: Developing the legacy of Henri Tajfel (pp. 337-358). Oxford: Butterworth-Heinemann.

Brubaker, R. (1996). Nationalism reframed: Nationhood and the national question in the new Europe. Cambridge: Cambridge University Press.

Calhoun, C. (1991). Indirect relationships and imagined communities: Large-scale social integration and the transformation of everyday life. In P. Bourdieu, J. S. Coleman (Eds.), Social theory for a changing society. Boulder: Westview Press.

Calhoun, C. (1995). Critical social theory. Oxford: Blackwe.

Condor, S. (1996). Unimagined community: Social psychological issues concerning English national identity. In G. M. Breakwell, \& E. Lyons (Eds.), Changing European identities: Social psychological analyses of social change (pp. 41-68). Oxford: Butterworth-Heinemann.

Condor, S. (2000). Pride and prejudice: Identity management in English peoples talk about 'this country'. Discourse and Society, 11, 163-193.

Condor, S. (2006). Temporality and collectivity: Diversity, history, and the rhetorical construction of national entitativity. British Journal of Social Psychology, 45, 657-682.

Condor, S. (in press). Sense and sensibility: The conversational etiquette of English national selfidentification. In A. Aughey \& C. Berberich, (Eds.), These Englands: A conversation on national identity. Manchester: University Press.

Conway, J., \& Singh, J. (2009). Is the world social forum a transnational public sphere? Theory, Culture \& Society, 26, 61-84.

Crump, S. A., Hamilton, D. L., Sherman, S. J., Lickel, B., \& Thakkar, V. (2010). Group entitativity and similarity: Their differing patterns in perceptions of groups. European Journal of Social Psychology, 40, 1212-1230.

Dumont, L. (1971). Homo hierarchicus. Essai sur le système des castes. Paris: Gallimard. 
Fenton, S. (2007). Indifference towards national identity: What young adults think about being English and British. Nations and Nationalism, 13, 321-339.

Fraser, N. (2007). Transnationalizing the public sphere: On the legitimacy and efficacy of public opinion in a post-westphalian world. Theory, Culture \& Society, 24, 7-30.

Gergen, K. J. (1991). The satured self. New York: Basic Books.

Giddens, A. (1990). The consequences of modernity. Cambridge: Polity Press.

Habermas, J. (1994). Citizenship and national identity. In B. van Steenbergen The condition of citizenship (pp. 20-36). London: Sage.

Habermas, J. (1998). The postnational constellation. Cambridge: Polity Press.

Hannerz, U. (1996). Transnational connections. London: Routledge.

Heath, A., \& Roberts, J. (2008). British identity: Its sources and possible implications for civic attitudes and behaviour. London: Ministry of Justice.

Hobsbawm, E. (1990). Nations and nationalism since 1780: Programme, myth, reality. Cambridge: Cambridge University Press.

Hooson D. (Ed.), (1994). Geography and national identity. Oxford: Blackwell.

Hopkins, N. P., Reicher, S. D., \& Harrison, K. (2006). Young person's deliberations on geographic mobility: Identity and cross-border relocation. Political Psychology, 27, 227-245.

Kostakopoulou, D. (2008). The future governance of citizenship. Cambridge: Cambridge University Press.

Kymlicka, W. (1995). Multicultural citizenship. Oxford: Oxford University Press.

Lagos, T. G. (2002). Global citizenship: Towards a definition. Available at: http://depts.washington. edu/gcp/pdf/globalcitizenship.pdf [Retrieved on 8th April 2010]

Marks, G. (1999). Territorial identities in the European Union. In J. J. Anderson (Ed.), Regional integration and democracy: Expanding on the European experience. Boulder: Rowan \& Littlefield.

Marshall, T. H. (1950). Citizenship and social class and other essays. Cambridge: Cambridge University Press.

Miller, D. (1995). On nationality. Oxford: Oxford University Press.

Miller, D. (2000). Citizenship and national identity. Cambridge: Polity.

Norris, P. (2000). Global governance and cosmopolitan citizens. In J. S. Nye Jr, \& E. Kamarck Globalization and governance (pp. 155-177). Washington, DC: Brookings Institution Press.

Parekh, B. (2003). Cosmopolitanism and global citizenship. Review of International Studies, 29, 3 17.

Passini, S., \& Morselli, D. (2011). In the Name of Democracy: Disobedience and Value-Oriented Citizenship. Journal of Community and Applied Social Psychology.

Reicher, S. D., \& Haslam, S. A. (2009). Beyond help: A social psychology of collective solidarity and social cohesion. In M. Snyder, \& S. Sturmer (Eds.), The psychology of helping: New directions in the study of intergroup prosocial behavior (pp. 289-309). Oxford, UK: Blackwell.

Reicher, S. D., \& Hopkins, N. (2001). Self and nation: Categorization, contestation and mobilization. London: Sage.

Reicher, S. D., Hopkins, N. P., \& Harrison, K. (2006). Social identity and spatial behaviour: The relationship between national category salience, the sense of home, and labour mobility across national boundaries. Political Psychology, 27, 247-263.

Rose, R. (1985). National pride in cross-national perspective. International Social Science Journal, 37, 85-96.

Scharpf, F. W. (1996). Negative and positive integration in the political economy of European welfare states. In G. Marks, F. W. Scharpf, P. Schmitter, \& W. Streeck (Eds.), Governance in the European Union (pp. 15-39). London: Sage.

Sears, A., Davies, I., \& Reid, A. (2008). From Britishness to nothingness and back again: Looking for a way forward in citizenship education. Paper presented at Britishness, Identity, Citizenship: The View from Abroad, University of Huddersfield, UK, 5-6 June 2008.

Sindic, D. (2008). National identities: Are they declining? Futurelab: UK Department for Children, Schools and Families' Beyond Current Horizons Project. Available at: http://www.beyondcurrenthorizons.org.uk/national-identities-are-they-declining/ [Retrieved on 25 January 2009].

Sindic, D. (2010). National identity, separatism, and supra-nation integration: Attitudes towards Britain and Europe in Scotland. Saarbrücken: VDM Verlag Dr. Müller. 
Smith, A. D. (1998). Nationalism and modernism: A critical survey of recent theories of nations and nationalism. London: Routledge.

Smith, T. W., \& Jarkko, L. (1998). National pride: A cross-national analysis. GSS Report No. 19, NORC: University of Chicago.

Tajfel, H. (1981). Human groups and social categories. Cambridge: Cambridge University Press.

Tajfel, H., \& Turner, J. C. (1979). An integrative theory of intergroup relations. In S. Worchel, \& W. G. Austin (Eds.), Psychology of intergroup relations. Monterey, CA: Brooks-Cole.

Tamir, Y. (1993). Liberal nationalism. Princeton: Princeton University Press.

Taylor, C. (1994). The politics of recognition. In C. Taylor (Ed.), Multiculturalism: Examining the politics of recognition. Princeton: Princeton University Press.

Tomlinson, J. (1991). Cultural imperialism: A critical introduction. London: Pinter.

Turner, J. C., Oakes, P. J., Haslam, S. A., \& McGarty, C. (1994). Self and collective: Cognition and social context. Personality and Social Psychology Bulletin, 20, 454-463.

Waldzus, S., Mummendey, A., Wenzel, M., \& Weber, U. (2003). Towards tolerance: Representations of superordinate categories and perceived ingroup prototypicality. Journal of Experimental Social Psychology, 39, 31-47.

Wills, M. (2008). The politics of identity. Available at: http://www.justice.gov.uk/news/sp280308. htm [Retrieved on 7 April 2010].

Young, I. M. (2003). Europe and the global south: Towards a circle of equality. Available at: http:// www.16beavergroup.org/mtarchive/archives/000426.php [Retrieved on 25 April 2010]. 